\title{
Cloning, heterologous expression and pharmacological characterization of a kappa opioid receptor from the brain of the rough-skinned newt, Taricha granulosa
}

\author{
C Samuel Bradford, Eliza A Walthers, Brian T Searcy and Frank L Moore \\ Department of Zoology, 3029 Cordley Hall, Oregon State University, Corvallis, Oregon 97331, USA
}

(Requests for offprints should be addressed to S Bradford; Email: bradforc@science.oregonstate.edu)

\begin{abstract}
A full-length cDNA that encodes a kappa (к) opioid receptor has been isolated from the brain of a urodele amphibian, the rough-skinned newt Taricha granulosa. The deduced protein contains 385 amino acids and possesses features commonly attributed to $\mathrm{G}$ protein-coupled receptors, such as seven putative transmembrane domains. The newt $\kappa$ receptor has $75 \%$ sequence identity to $\kappa$ opioid receptors cloned from mammals, and $66 \%$ sequence identity to the $\kappa$ opioid receptor reported for the zebrafish, with the greatest divergence in the extracellular $\mathrm{N}$-terminus, the second and third extracellular loops and the intracellular C-terminus. Membranes isolated from COS-7 cells expressing the newt $\kappa$ receptor possessed a single, high-affinity $\left(K_{\mathrm{d}}=1.5 \mathrm{nM}\right)$ binding site for the $\kappa$-selective agonist U69593. In competition binding assays, the expressed newt $\kappa$ receptor displayed high affinity for the $\kappa$-selective agonists GR89696, dynorphin $\mathrm{A}(1-13), \mathrm{U} 69593, \mathrm{U} 50488$ and BRL52537, as well as the $\kappa$-selective antagonist nor-binaltorphimine and the non-selective antagonist naloxone. Rank order potencies and affinity constants were similar in competition binding studies that used either whole brain homogenates or membranes isolated from COS-7 cells expressing the newt $\mathrm{k}$ receptor. The expressed receptor displayed essentially no affinity for the $\delta$-selective agonist DPDPE ([d-penicillamine, d-penicillamine]enkephalin), but showed moderate affinity for the $\mu$-selective agonist DAMGO ([d-Ala-MePhe, Gly-ol]enkephalin) and moderately high affinity for nociceptin (orphanin FQ), the endogenous ligand for the opioid receptor-like $(\mathrm{ORL}) 1$ receptor. These findings support the conclusions that a gene for the $\kappa$ opioid receptor is expressed in amphibians and that the pharmacology of the newt $\kappa$ receptor closely matches mammalian $\kappa$ opioid receptors. However, the functional dichotomy between the classic opioid receptors $(\kappa, \delta, \mu)$ and ORL1 appears less strict in amphibians than in mammals.
\end{abstract}

Journal of Molecular Endocrinology (2005) 34, 809-823

\section{Introduction}

Kappa $(\kappa)$, delta $(\delta)$, mu $(\mu)$ and ORL1 (opioid receptor-like) represent the four main classes of opioid receptors, which are defined and distinguished by primary structures, anatomical distributions, pharmacological profiles and physiological functions. Opioid receptors belong to the superfamily of $\mathrm{G}$ protein-coupled receptors possessing seven transmembrane domains (Janecka et al. 2004, Waldhoer et al. 2004), and when activated, typically produce an inhibition of adenylyl cyclase activity (Reisine \& Bell 1993) and the modulation of calcium and potassium conductances (Darlison et al. 1997).

$\kappa$ opioid receptors (named for the prototypic ligand ketocyclazocine) selectively bind endogenous peptides derived from pro-dynorphin (Chavkin et al. 1982), as well as synthetic benzomorphans (Goldstein \& Naidu 1989) and arylacetamides such as U50488 (Lahti et al. 1982, Piercey et al. 1982) and U69593 (Lahti et al. 1985). $\kappa$ receptors participate in a wide range of physiological functions, including pain perception, feeding and drinking behavior, water balance, gut motility, temperature regulation and cardiovascular control (Bloom 1983). Because activation of $\kappa$ receptors produces analgesia in the absence of primary reinforcement (Meng et al. 1993), the $\kappa$ receptor has been an attractive target for development of analgesic drugs with low abuse potential. Although early $\kappa$ agonists evaluated in humans showed a predisposition for eliciting central nervous system disturbances (altered perception, dysphoria, psychotomimesis) (Pfeiffer et al. 1986), $\kappa$-related drugs developed more recently do not provoke such adverse side effects and have been demonstrated to be neuroprotective and potentially effective in the treatment of stroke and ischemic brain attacks (Tortella et al. 1997).

Many early studies describing the isolation, solubilization, purification and partial characterization of $\kappa$ opioid receptors were conducted using membranes prepared from the brains of toads (Bufo marinus) (Ruegg et al. 1980, 1981, Cone \& Goldstein 1982, Simon et al. 1982) or frogs (Rana pipiens) (Benyhe et al. 1994, Simon et al. 1984, 
1987, 1990, Stevens et al. 1987), because $\kappa$ receptors were found to be highly abundant in the amphibian central nervous system. Early experiments with frogs and toads demonstrated the presence of immunoreactive dynorphin in the brain (Cone \& Goldstein 1982) and reported antinociceptive responses to exogenously administered dynorphin (Stevens et al. 1987). In contrast, most studies describing molecular cloning of $\kappa$ opioid receptors have focused on mammalian species; nucleic acid/amino acid sequence data correlated with binding pharmacology for non-mammalian species are nonexistent.

To date, full-length cDNA sequences have been reported for mouse (Yasuda et al. 1993), rat (Chen et al. 1993, Meng et al. 1993, Minami et al. 1993, Yakovlev et al. 1995), guinea pig (Xie et al. 1994) and human (Mansson et al. 1994, Simonin et al. 1995); a partial sequence for a bovine $\kappa$ receptor $(\mathrm{Li}$ et al. 1996) is also available. Partial sequences for $\kappa$ opioid receptors have been reported for two teleost fishes, white sucker (Catostomus commersoni) (Li et al. 1996, Darlison et al. 1997) and bass (Morone saxatilis) ( $\mathrm{Li}$ et al. 1996), and a full-length cDNA sequence for a zebrafish (Danio rerio) $\kappa$ receptor ('ZFOR 3') has been deposited in the GenBank database (Accession AF285173) along with the predicted amino acid sequence (GenBank Accession NP_878306). Among avian species, a $\kappa$ opioid receptor has been identified and partially characterized pharmacologically in a passerine songbird (Funco hyemalis) (Deviche et al. 1993). Among amphibians, a cDNA sequence for a $\kappa$-like opioid receptor from the northern grass frog (R. pipiens) has been deposited in the GenBank database (Accession AF530573), but this sequence includes a base insertion that leads to a frameshift in the potential coding region. For this reason the identification or status of any protein(s) encoded by the grass frog cDNA sequence remains unclear.

Among urodele amphibians, no cloning experiments directed at $\kappa$ opioid receptors have been reported to date, despite compelling evidence for the existence and physiological relevance of $\kappa$ receptors in these animals. In male rough-skinned newts (Taricha granulosa), ethylketocyclazocine and bremazocine ( $\kappa$-selective receptor agonists) suppress sexual behavior (amplectic clasping of females); the effect of bremazocine is reversed in a dose-dependent fashion by treatment with naloxone (a non-selective opioid antagonist) (Deviche \& Moore 1987). Bremazocine suppresses spontaneous (Deviche et al. 1989) but not corticotropin-releasing factor-induced (Lowry et al. 1990) locomotor activity in male newts, supporting the idea that opioids may be important regulators of amphibian behavior. Finally, some but not all $\kappa$-selective agonists are capable of displacing $\left[{ }^{3} \mathrm{H}\right]$ corticosterone from the membrane glucocorticoid receptor identified in the Taricha brain (Evans et al. 2000). This membrane steroid receptor mediates rapid behavioral responses, such as suppression of amplectic clasping (Orchinik et al. 1991, Moore \& Orchinik 1994), through a mechanism that is modulated by $\mathrm{Mg}^{2+}$ and guanyl nucleotides (Orchinik et al. 1992). Together, these observations have prompted speculation that the high-affinity membrane binding site for corticosterone is, in fact, located on a $\kappa$-like opioid receptor (Evans et al. 2000).

The current study was undertaken in an effort to characterize the $\kappa$ opioid receptor $(\mathrm{s})$ present in the brain of a urodele amphibian, the rough-skinned newt $T$. granulosa. Here we report the molecular cloning and heterologous expression of a full-length cDNA sequence that encodes the newt brain $\kappa$ opioid receptor (nKOR). The deduced amino acid sequence of nKOR was compared with the other full-length $\kappa$ opioid receptors that have been cloned to date. Binding pharmacology was characterized for nKOR transiently expressed in COS-7 cells, and compared with the results of similar binding assays performed using synaptosome preparations isolated from whole newt brains. This is the first time a non-mammalian $\kappa$ opioid receptor has been cloned, expressed in a heterologous system, and characterized.

\section{Materials and methods}

\section{Animals}

Newts were collected from local (Benton County, OR, USA) freshwater ponds. All animals were housed, handled and used in accordance with federal and institutional guidelines.

\section{Degenerate PCR}

Full-length cDNA sequences available from the GenBank database for various species (human, mouse, rat, pig, guinea pig, zebrafish) were aligned using ClustalW, and degenerate oligonucleotide primers were designed using Primer3 software (Rozen \& Skaletsky 2000) based on highly conserved regions in the $\mathrm{N}$-terminus and first intracellular loop. The sequences of the sense and the antisense primers (purchased from The Great American Gene Company) were 5'-GCACAT CTCYCGRGCGATCG-3' and 5'-GGTCGACRCTCA TCATGGTCAA-3' respectively. Total RNA was prepared from the pooled brains of six adult male newts according to the protocol supplied with the ToTALLY RNA kit (Ambion, Austin, TX, USA). This procedure was performed several times, on different dates, in order to obtain multiple RNA pools prepared independently. cDNA was obtained by RT-PGR using a cDNA first-strand synthesis kit (Fermentas, Hanover, MD, USA). This procedure was performed several times, on different dates, using different RNA templates. 
For degenerate PCR, primers, dNTPs, Taq polymerase and newt brain cDNA template were used in PCR reactions with the following cycling conditions: $94{ }^{\circ} \mathrm{C} \times 3 \mathrm{~min} ; 4$ cycles of $94{ }^{\circ} \mathrm{C} \times 45$ s, $55^{\circ} \mathrm{C} \times 45 \mathrm{~s}$, $72{ }^{\circ} \mathrm{C} \times 1$ min $30 \mathrm{~s} ; 34$ cycles of $94{ }^{\circ} \mathrm{C} \times 30 \mathrm{~s}, 55^{\circ} \mathrm{C} \times 30$ $\mathrm{s}, 72{ }^{\circ} \mathrm{C} \times 1 \mathrm{~min}$; terminal extension at $72^{\circ} \mathrm{C} \times 7 \mathrm{~min}$. Negative controls included autoclaved water in place of the cDNA template. PCR products were separated on a $1.4 \%$ agarose gel, stained with ethidium bromide, and visualized with UV light. PCR products of the appropriate size ( $309 \mathrm{bp}$ ) were purified from gels using a GelSpin DNA Purification Kit (MO BIO, Solana Beach, CA, USA), ligated into the pCR4-TOPO vector (Invitrogen), and transformed into TOP10 Escherichia coli competent cells. Following overnight incubation, plasmid DNA was isolated from minipreps and purified by alkaline lysis using a Qiaprep kit (Qiagen). Purified DNA was sequenced by the Central Services Laboratory at Oregon State University. Sequences were analyzed with a BLAST-N 2.0 search tool provided by NCBI.

\section{Rapid amplification of cDNA ends (RACE)-PCR}

Clones identified by degenerate PCR possessing the highest sequence identity to known $\kappa$ opioid receptors were used to design gene-specific primers for RACEPCR. The sense primer (for $3^{\prime}$ RACE) was 5'-GGGA AGGTGCTCTGTAAAATAGTC-3'; the antisense primer (for 5'RACE) was 5'-CATGACGAAGGAGT TTCGCACCAG-3'. Gene-specific primers were purchased from One Trick Pony (Ransom Hill Bioscience, Ramona, CA, USA). 3'RACE-ready cDNA was prepared from newt brain RNA according to the FirstChoice RLM-RACE kit protocol (Ambion). 3'RACE-ready cDNA was used in conjunction with the nKOR gene-specific sense primer and the Ambion 3' 'Inner' antisense primer in a $3^{\prime}$ RACE-PCR reaction according to the kit protocol and recommended cycling conditions. Following agarose gel electrophoresis, a PCR product (approximately $1.4 \mathrm{~kb}$ ) was gel purified, sub-cloned, and sequenced as described above.

5'RACE-ready cDNA was synthesized from newt brain RNA according to Ambion's RLM-RACE kit protocol. 5'RACE-PCR reactions were carried out using the Ambion kit reagents and protocol, the Ambion 'Outer RACE' sense primer and a 5'RACE genespecific antisense primer with the following cycling conditions: $94{ }^{\circ} \mathrm{C}$ for $3 \mathrm{~min}$; 4 cycles of $94{ }^{\circ} \mathrm{C} \times 45 \mathrm{~s}$, $62{ }^{\circ} \mathrm{C} \times 45 \mathrm{~s}, 72{ }^{\circ} \mathrm{C} \times 1 \mathrm{~min} ; 34$ cycles of $94{ }^{\circ} \mathrm{C} \times 30 \mathrm{~s}$, $62{ }^{\circ} \mathrm{C} \times 30 \mathrm{~s}, 72^{\circ} \mathrm{C} \times 1 \mathrm{~min}$; and $72{ }^{\circ} \mathrm{C} \times 7 \mathrm{~min}$.

Regions of overlapping and identical sequences among the original degenerate PCR product and the 5'RACE and 3'RACE products were joined using SeqMerge software (Accelyrs, San Diego, CA, USA) to produce a contiguous sequence representing the full-length nKOR cDNA. New gene-specific primers were designed at the extreme $5^{\prime}$ and $3^{\prime}$ ends of the open reading frame, and the complete coding region was subsequently PCR amplified using a high-fidelity Pfx proof-reading polymerase (Invitrogen) and subcloned three separate times to obtain a consensus sequence.

\section{Phylogenetic tree construction}

Available full-length opioid receptor protein sequences for species other than T. granulosa were obtained from GenBank. Amino acid sequences were aligned using ClustalX (v1.81) (Thompson et al. 1997). The alignment was analyzed using the bootstrap and protein sequence parsimony components of PHYLIP $3 \cdot 6$ (Felsenstein $1989,2004)$ to generate a phylogenetic tree. The tree was rooted in Rattus norvegicus somatostatin receptor type 1 , representing a family of $\mathrm{G}$ protein-coupled receptors closely related to the opioid receptors (Pfeiffer et al. 2002).

\section{Transient expression of nKOR in COS-7 cells}

The full-length nKOR cDNA was sub-cloned into the mammalian expression vector pcDNA3.1/V5-HisTOPO (Invitrogen) and individual clones were analyzed for correct orientation with respect to the GMV promoter. COS-7 (African green monkey kidney) cells (American Type Culture Collection, Manassas, VA, USA) were cultured in $10 \mathrm{~cm}$ tissue culture plates at $37{ }^{\circ} \mathrm{C}$ under $5 \% \mathrm{CO}_{2}$ in Dulbecco's Modified Eagle's Medium (Mediatech Cellgro, Herndon, VA, USA) supplemented with $2 \mathrm{mM}$ L-glutamine (Invitrogen) and $10 \%$ fetal bovine serum (Hyclone, Logan, UT, USA). Transient expression was achieved by transfecting plates (90-95\% confluency) using Lipofectamine 2000 reagent (Invitrogen) diluted with Opti-MEM medium (Invitrogen). For each $10 \mathrm{~cm}$ culture plate, $24 \mu \mathrm{g}$ DNA in $1.5 \mathrm{ml}$ Opti-MEM and $60 \mu \mathrm{l}$ Lifpofectamine 2000 in $1.5 \mathrm{ml}$ Opti-MEM were added to a plate containing $12 \mathrm{ml}$ growth medium. Six hours after transfection, the lipofection mixture was aspirated and replaced with $14 \mathrm{ml}$ of fresh growth medium.

\section{Preparation of cos-7 cell membranes}

Forty-eight hours after transfection, cells were washed twice with room temperature PBS and harvested under homogenization buffer ( $2 \mathrm{ml} /$ plate) using a cell scraper. Suspended cells were homogenized in chilled buffer (25 mM Hepes, $100 \mu \mathrm{M}$ phenylmethylsulfonyl fluoride (PMSF), $100 \mu \mathrm{g} / \mathrm{ml}$ trypsin inhibitor, $0.7 \mu \mathrm{g} / \mathrm{ml}$ leupeptin, $100 \mu \mathrm{g} / \mathrm{ml}$ bacitracin) using a chilled glass-on-glass Dounce homogenizer. Homogenates were centrifuged 
for $10 \mathrm{~min}$ at $45000 \mathrm{~g}$ at $4{ }^{\circ} \mathrm{C}$. Supernatants were discarded and pellets were resuspended in homogenization buffer $(1 \mathrm{ml} /$ plate $)$ and centrifuged a second time. Supernatants were discarded and cell membrane pellets were resuspended in binding buffer ( $250 \mu \mathrm{l} /$ plate) containing $\mathrm{MgCl}_{2}$ (see Binding Assays described below), snap-frozen in liquid $\mathrm{N}_{2}$, and stored at $-80{ }^{\circ} \mathrm{C}$ until use. In the course of this study, multiple transfections were performed; however, tissues from different transfections were not pooled, and in a given binding assay all tissues used were obtained from a single transfection. The concentration of total protein in membrane preparations was determined using a colorimetric protein assay (Pierce, Rockford, IL, USA).

\section{Preparation of neuronal P2 membranes from whole newt brains}

Neuronal membranes (P2 membrane pellets) were prepared according to the method of Whittaker (1969), as modified by Orchinik et al. (1991). Brains were removed from anesthetized adult male newts and placed in $0.3 \mathrm{ml}$ of chilled homogenization buffer $(0.32 \mathrm{M}$ sucrose, $5 \mathrm{mM}$ HEPES, pH 7.45, $100 \mu \mathrm{M}$ PMSF) per $\mathrm{mg}$ wet tissue weight. Brains were homogenized in a Teflon-on-glass Dounce homogenizer. The homogenate was centrifuged at $1000 \boldsymbol{g}$ for $10 \mathrm{~min}$ at $4{ }^{\circ} \mathrm{C}$, after which the supernatant was transferred to a clean centrifuge tube. The pellet $(\mathrm{P} 1)$ was resuspended in the original volume of homogenization buffer and centrifuged again, as above. The new supernatant was added to the first supernatant and the pellet discarded. Pooled supernatants were centrifuged at $30000 \boldsymbol{g}$ for $40 \mathrm{~min}$ at $4{ }^{\circ} \mathrm{C}$. The pellet (P2) was snap-frozen in liquid $\mathrm{N}_{2}$, thawed on ice, and resuspended in $0.18 \mathrm{ml} / \mathrm{mg}$ (original tissue weight) of $25 \mathrm{mM}$ HEPES, $10 \mathrm{mM}$ EDTA, pH $7 \cdot 45$, $100 \mu \mathrm{M}$ PMSF. The suspension of P2 was incubated at $4{ }^{\circ} \mathrm{C}$ for $2 \mathrm{~h}$, to allow for dissociation of endogenous ligand(s), and centrifuged at $40000 \boldsymbol{g}$ for $15 \mathrm{~min}$ at $4{ }^{\circ} \mathrm{C}$. Supernatant was discarded and the final pellet was snap-frozen in liquid $\mathrm{N}_{2}$ and stored at $-80{ }^{\circ} \mathrm{C}$.

\section{Binding assays}

Saturation and competition binding assays were performed in buffer consisting of $25 \mathrm{mM}$ Hepes (pH 7.45) containing $10 \mathrm{mM} \mathrm{MgCl}_{2}, 100 \mu \mathrm{M}$ PMSF, trypsin inhibitor $(100 \mu \mathrm{g} / \mathrm{ml})$, leupeptin $(0.7 \mu \mathrm{g} / \mathrm{ml})$ and bacitracin $(100 \mu \mathrm{g} / \mathrm{ml})$. Frozen membrane pellets (COS-7 or P2) were thawed on ice and diluted with binding buffer to achieve a final protein concentration of $50 \mu \mathrm{g}$ per binding reaction. For saturation experiments, various concentrations of $\left[{ }^{3} \mathrm{H}\right] \mathrm{U} 69593(41 \cdot 4 \mathrm{Ci} / \mathrm{mmol}$; Perkin Elmer Life Sciences, Boston, MA, USA) were used in the presence of $10 \mu \mathrm{M}$ nor-binaltorphimine (nor-BNI) (TOCRIS, Ellisville, MO, USA). Competition binding experiments were performed using $1-2 \mathrm{nM}$ $\left[{ }^{3} \mathrm{H}\right] \mathrm{U} 69593$ and various doses $\left(10^{-12}\right.$ to $\left.10^{-4} \mathrm{M}\right)$ of non-radioactive competitors. GR89696, U50488, BRL52537 and [D-Ala-MePhe, Gly-ol] enkephalin (DAMGO) were purchased from TOCRIS; dynorphin A(1-13) amide was from Phoenix Pharmaceuticals (Belmont, CA, USA); U69593 was from Sigma-Aldrich; nociceptin and [D-penicillamine, D-penicillamine] enkephalin (DPDPE) were from Multiple Peptide Systems (San Diego, CA, USA). Non-specific binding was defined as radioactivity remaining bound in the presence of $10 \mu \mathrm{M}$ non-radioactive U69593. Triplicate samples were run at each dose for both total and non-specific binding. Assays were conducted at $4{ }^{\circ} \mathrm{C}$ for $4 \mathrm{~h}$ with gentle mixing (80 r.p.m. on an orbital shaker). At the end of the incubation period, bound and free ligand were separated by rapid filtration over GF/C filters (presoaked with $0 \cdot 25 \%$ polyethyleneimine for $30 \mathrm{~min}$ in inhibition experiments with peptide ligands) under vacuum using a Brandel (Gaithersburg, MD, USA) cell harvester. Filters were washed twice with $4 \mathrm{ml}$ of chilled $\left(4^{\circ} \mathrm{C}\right.$ ) Hepes $/ \mathrm{MgCl}_{2}$ (pH 7.45) buffer. Radioactivity in the filters was determined by liquid-scintillation counting on a Beckman LS 6500 scintillation counter. Binding data were analyzed using GraphPad Prism software (GraphPad Software, San Diego, CA, USA).

\section{Results}

\section{cDNA and deduced amino acid sequence analyses}

The degenerate PCR procedure yielded an amplified product of $269 \mathrm{bp}$, representing a cDNA sequence encoding a peptide of 81 amino acids. BLAST analysis of the deduced amino acid sequence predicted a hypothetical protein characterized by putative conserved domains consistent with membership in the family of proteins containing seven transmembrane domains (rhodopsin family), and showed highest sequence identity to mammalian $\kappa$ opioid receptors. RACE-PCR yielded additional nucleotide sequences overlapping the original 'core' sequence at each end, and allowed construction of a single, contiguous, nucleotide sequence.

The contiguous cDNA amplified from degenerate and RACE-PCR performed using newt brain cDNA template is shown in Fig. 1. This sequence contains an open reading frame spanning nucleotides $1-1158$. The sequence of the open reading frame was independently verified at least three times, using different preparations of newt brain cDNA prepared independently of one another. No products were amplified in negative controls that included autoclaved water in place of the cDNA template. Immediately upstream of the putative start codon shown in Fig. 1 is the sequence GTTATGG, a variation on the Kozak consensus sequence (for efficient initiation of transcription) (G/A)NNATGG 


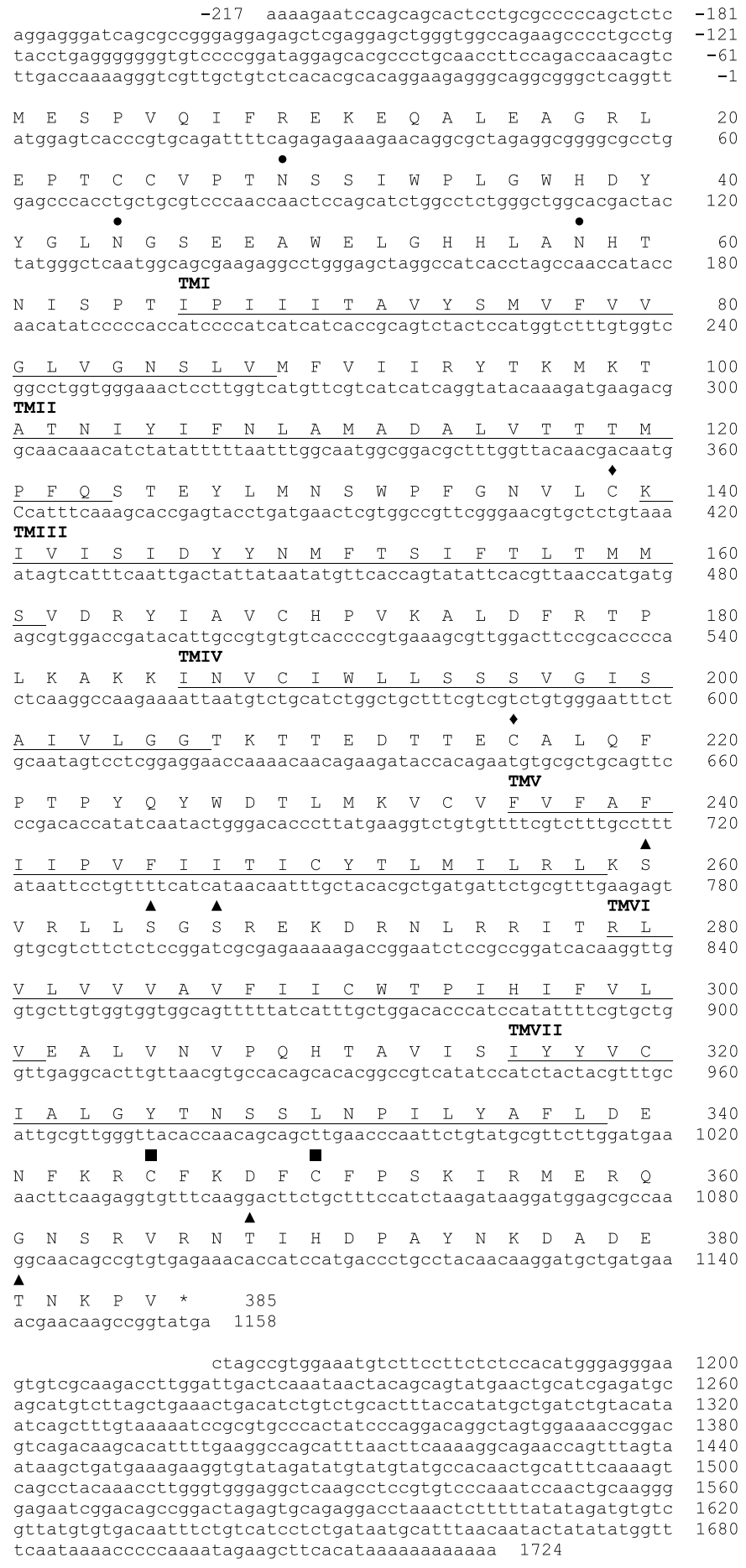

Figure 1 Nucleotide and deduced amino acid sequences for the nKOR cDNA (GenBank accession number AY725197). Within the coding region, putative transmembrane domains (TMI-TMVII) are underlined; an asterisk marks the stop codon. Consensus $\mathrm{N}$-linked glycosylation sites $(\bullet)$ are indicated (symbol above the affected amino acid), as are potential sites for disulfide bond formation ( $\downarrow)$, post-translational palmitoylation ( $\square$ ) and phosphorylation ( $(\mathbf{\Delta})$. 
(Kozak 1989). The open reading frame encodes a protein that is 385 amino acids in length and has an estimated molecular mass of $43833 \mathrm{Da}$ (in the absence of post-translational modification). BLAST analysis of this amino acid sequence detected seven conserved transmembrane domains and indicated highest sequence identity to $\mathrm{G}$ protein-coupled receptors in general, and to mammalian $\kappa$ opioid receptors specifically. Hydrophobicity analysis also predicted the presence of seven transmembrane domains. Assignment of putative membrane-spanning regions are indicated in Figs 1 and 2, based on results obtained using online protein topology servers (Moller et al. 2001), including TMHMM2.0 (Krogh et al. 2001) and HMMTOP2.0 (Tusnady \& Simon 2001). The predicted protein contains several sites for post-translational modification that are conserved among $\mathrm{G}$ protein-coupled receptors, including consensus sites for N-linked glycosylation (asparagine residues in the extracellular $\mathrm{N}$-terminal domain), and amino acid substrates for palmitoylation and phosphorylation within the putative intracellular C-terminal domain. Cysteine residues in the first two putative extracellular loops provide for the formation of a disulfide bond. The sequence Asp-Arg-Tyr (DRY) in the second intracellular loop (immediately following TMIII) is also a feature conserved among members of the $\mathrm{G}$ protein-coupled receptor superfamily. The sequence shown in Fig. 1 has been deposited in the GenBank database (Accession AY725197).

Figure 2 compares the deduced amino acid sequence of the nKOR with zebrafish and mammalian $\kappa$ receptors (sequences from GenBank). The newt receptor is a protein consisting of 385 amino acids, and is larger than that described for mammals (380 amino acids for all four species) or the zebrafish (377 amino acids). This size difference is accounted for mainly by the fact that the extracellular N-terminal domain of nKOR is larger than the corresponding region in the other receptors listed. nKOR shares approximately $75 \%(74 \cdot 2-76 \cdot 0 \%)$ amino acid sequence identity with the mammalian receptors, but only $66 \%$ identity with the $\kappa$ opioid receptor cloned from zebrafish. In general, the transmembrane domains, the intracellular loops and the first extracellular loop tend to be conserved among all species listed; the greatest divergences between the newt protein and that of the non-amphibian species occur in the extracellular $\mathrm{N}$-terminal domain, the intracellular C-terminal domain and the second and third extracellular loops (all of which are highly conserved among mammals).

A tree generated by the PHYLIP (v3.6) protein sequence parsimony method demonstrates that the newt amino acid sequence groups with the kappa opioid receptors, as opposed to the three other opioid receptor types $(\delta, \mu$ and ORL) that have been cloned from other vertebrates (Fig. 3).

\section{Transient expression of nKOR and binding pharmacology}

Saturation binding experiments using the $\kappa$-selective agonist $\left[{ }^{3} \mathrm{H}\right] \mathrm{U} 69593$ revealed the presence of a specific, saturable, high-affinity (estimated $K_{\mathrm{d}}=1.514 \mathrm{nM}$ ) binding site on membranes isolated from COS-7 cells transiently expressing nKOR, as shown in Fig. 4. At a dose equivalent to the estimated $K_{\mathrm{d}}$ for $\left[{ }^{3} \mathrm{H}\right] \mathrm{U} 69593$, specific binding was $95.4 \%$ of total binding. Saturation binding data were best fit using a one-site model for receptor-ligand interactions. No specific $\left[{ }^{3} \mathrm{H}\right] \mathrm{U} 69593$ binding was observed in parallel experiments conducted with membranes isolated from cells that were not transfected. A pharmacological profile of the cloned newt receptor was constructed, based on the ability of various opioid ligands to displace $\left[{ }^{3} \mathrm{H}\right] \mathrm{U} 69593$ from membranes of COS-7 cells transiently expressing nKOR (Fig. 5 and Table 1). The cloned receptor bound $\kappa$-specific ligands with high affinity $\left(K_{\mathrm{i}}=0 \cdot 3-6 \cdot 2 \mathrm{nM}\right)$; the observed rank order potency was GR89696> dynorphin A(1-13)> nor-BNI > U69593 > U50488> BRL52537.

The expressed receptor also demonstrated relatively high affinity for the non-selective opioid receptor antagonist naloxone $\left(K_{\mathrm{i}}=9 \cdot 6 \mathrm{nM}\right)$ and the ORL-selective ligand nociceptin $\left(K_{\mathrm{i}}=23.2 \mathrm{nM}\right)$. It exhibited lower affinity for the $\mu$-selective agonist DAMGO $\left(K_{\mathrm{i}}=55.4 \mathrm{nM}\right)$ and very low affinity for the $\delta$-selective agonist DPDPE $\left(K_{\mathrm{i}}=979 \mathrm{nM}\right)$.

\section{Binding assays using neuronal P2 membranes}

Competition binding experiments using neuronal P2 membranes prepared from Taricha brains yielded results very similar to those obtained with the cloned receptor transiently expressed in COS-7 cells (Fig. 6 and Table 1). P2 membrane pellets bound $\kappa$-specific ligands with high affinity $\left(K_{\mathrm{i}}=0 \cdot 3-5 \cdot 3 \mathrm{nM}\right)$; the observed rank order potency for displacing $\left[{ }^{3} \mathrm{H}\right] \mathrm{U} 69593$ was GR89696>dynorphin $\quad \mathrm{A}(1-13)>$ nor-BNI $>$ U50488> U69593 > BRL52537.

\section{Discussion}

The present investigation documents the cloning, heterologous expression, and pharmacological characterization of a $\mathrm{K}$ opioid receptor that is present in the brain of a urodele amphibian, the rough-skinned newt T. granulosa. This represents an extension of previous studies characterizing $\kappa$ ligand binding in tissue homogenates of whole brains from frogs or toads (Benyhe et al. 1994, Newman et al. 2002, Simon et al. 1982, Simon et al. 1984), and purification protocols (Borsodi et al. 1986, Simon et al. 1987, 1990) providing evidence for distinct $\kappa$ or $\kappa$-like receptors in the amphibian central nervous system. 
Taricha granulosa Homo sapiens

Rattus norvegicus Cavia porcellus

Mus musculus

Danio rerio

Taricha granulosa Homo sapiens

Rattus norvegicus Cavia porcellus

Mus musculus

Danio rerio

Taricha granulosa Homo sapiens

Rattus norvegicus Cavia porcellus

Mus musculus

Danio rerio

Taricha granulosa Homo sapiens

Rattus norvegicus

Cavia porcellus

Mus musculus

Danio rerio

Taricha granulosa

Homo sapiens

Rattus norvegicus

Cavia porcellus

Mus musculus

Danio rerio

Taricha granulosa Homo sapiens

Rattus norvegicus

Cavia porcellus

Mus musculus

Danio rerio

Taricha granulosa Homo sapiens

Rattus norvegicus

Cavia porcellus

Mus musculus

Danio rerio
Extracellular N-Terminus

MES-PVQIFREKEQALEAGRLEPTCCVPTNSSIWPLGWHDYYGLNGSEEAWELGHHLANH ...-.I....GEPGPTC.----.SA.L.P...A.FP. .AEPDS- . .AGSEDA---QLEP ...-.I....GEPGPTC.----.SA.LLP...S.FPN.AESDS- ..VGSEDQ---QLEP .GR-RR. GPAQPASE.P.----RNA. LLP. G.A. LP . A AEPDG- . . AGPQDE---QLEP ...-.I....GDPGPTCS----.SA.LLP...S.FPN.AESDS- . .VGSEDQ---QLES .D.NV . ...K. DKCPSSH----.EK. L.--NFT. QSAVS. I. N-SSLN.S.TT-----EQ

TMI

IL1

TMII

TNISPTIPIIITAVYSMVFVVGLVGNSLVMFVI IRYTKMKTATNIYIFNLAMADALVTTT

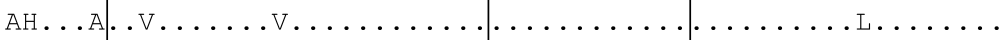

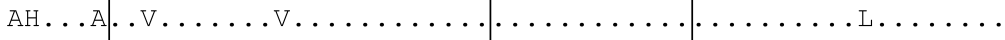

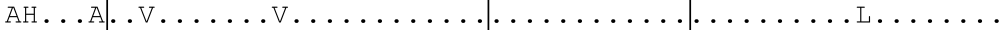

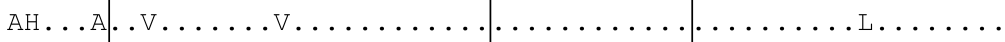

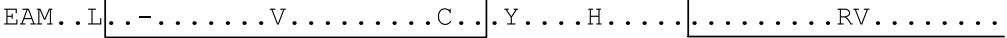

\section{EL1 TMIII $\quad$ IL2}

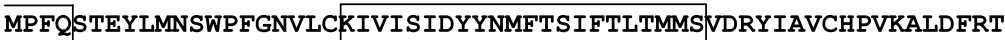

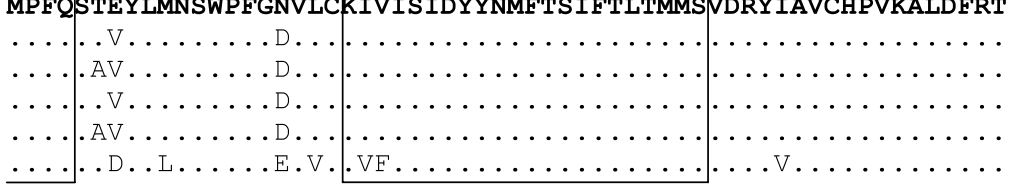

\section{TMIV}

EL2

PLKAKKINVCIWLLSSSVGISAIVLGGTKTTEDT--TECALQFP-TPYQYWDTLMKVCVE $\ldots \ldots I \ldots I \ldots \ldots \ldots \ldots \ldots \ldots$. . . VR . VDVI . S . . . DDD.SW . LF . I . .

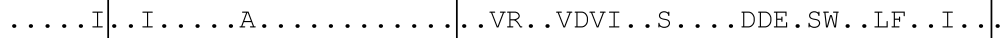

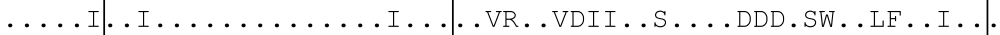

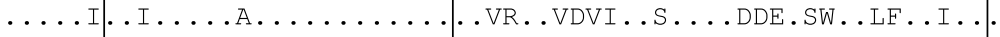

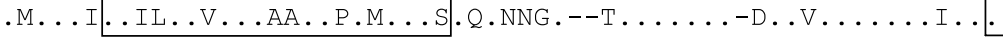

TMV IL3 TMVI VFAFIIPVFIITICYTLMILRLKSVRLLSGSREKDRNLRRITRLVLVVVAVFIICWTPIH

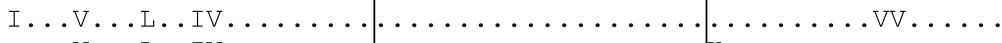

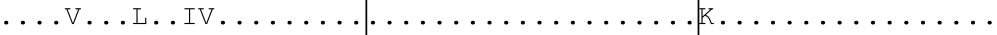

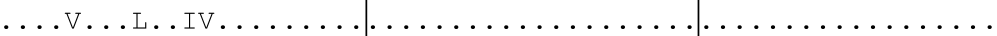

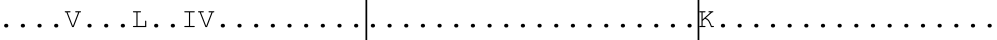

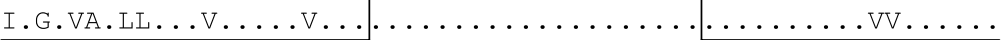

EL3

TMVII

IFVLVEALVN-VPQHTAVIS IYYVCIALGYTNSSLNPILYAFLDENFKRCFKDFCFPSKI

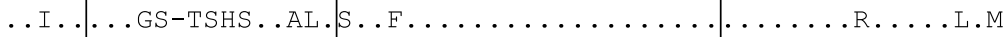

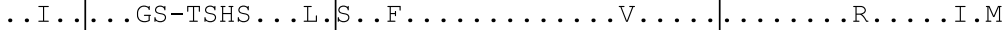

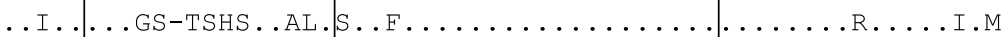

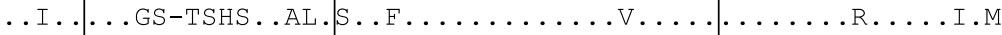

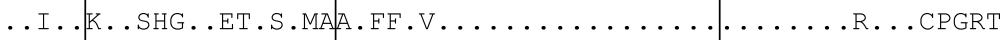

Intracellular C-Terminus

\begin{tabular}{|c|c|c|c|}
\hline WTIHD---PAYN & 385 & & \\
\hline$\ldots \mathrm{VQ} \cdot---\ldots \mathrm{LH}$ & 3 & $294)$ & {$[76$} \\
\hline .VQ.--- . SMR. VGGM. & 380 & $(290)$ & \\
\hline$\cdot---\ldots M$ & 380 & 7 & \\
\hline..$--- S \mathrm{SN}$ & & & \\
\hline$R \cdot V \ldots S$. & 7 & $(257)$ & \\
\hline
\end{tabular}

Figure 2 The deduced amino acid sequence of nKOR aligned with amino acid sequences of non-amphibian $\kappa$ opioid receptors. Dots indicate amino acid residues identical to those of $T$. granulosa; dashes indicate sequence gaps. Boxed sequences indicate putative transmembrane domains (TMI-TMVII); putative intracellular loops (IL1-IL3) and extracellular loops (EL1-EL3) are indicated. The total number of residues is listed at the end of each sequence, followed by the number of amino acids identical to the newt (in parentheses) and the overall percent identity (calculated using ClustalW and MVIEW - in brackets). Sequences for species other than $T$. granulosa were obtained from GenBank. Accession numbers: T. granulosa, AAU15126; Homo sapiens, NP_000903.2; Rattus norvegicus, NP_058863.1; Cavia porcellus, P41144 I; Mus musculus, NP_035141.1; Danio rerio, NP_878306.1. 


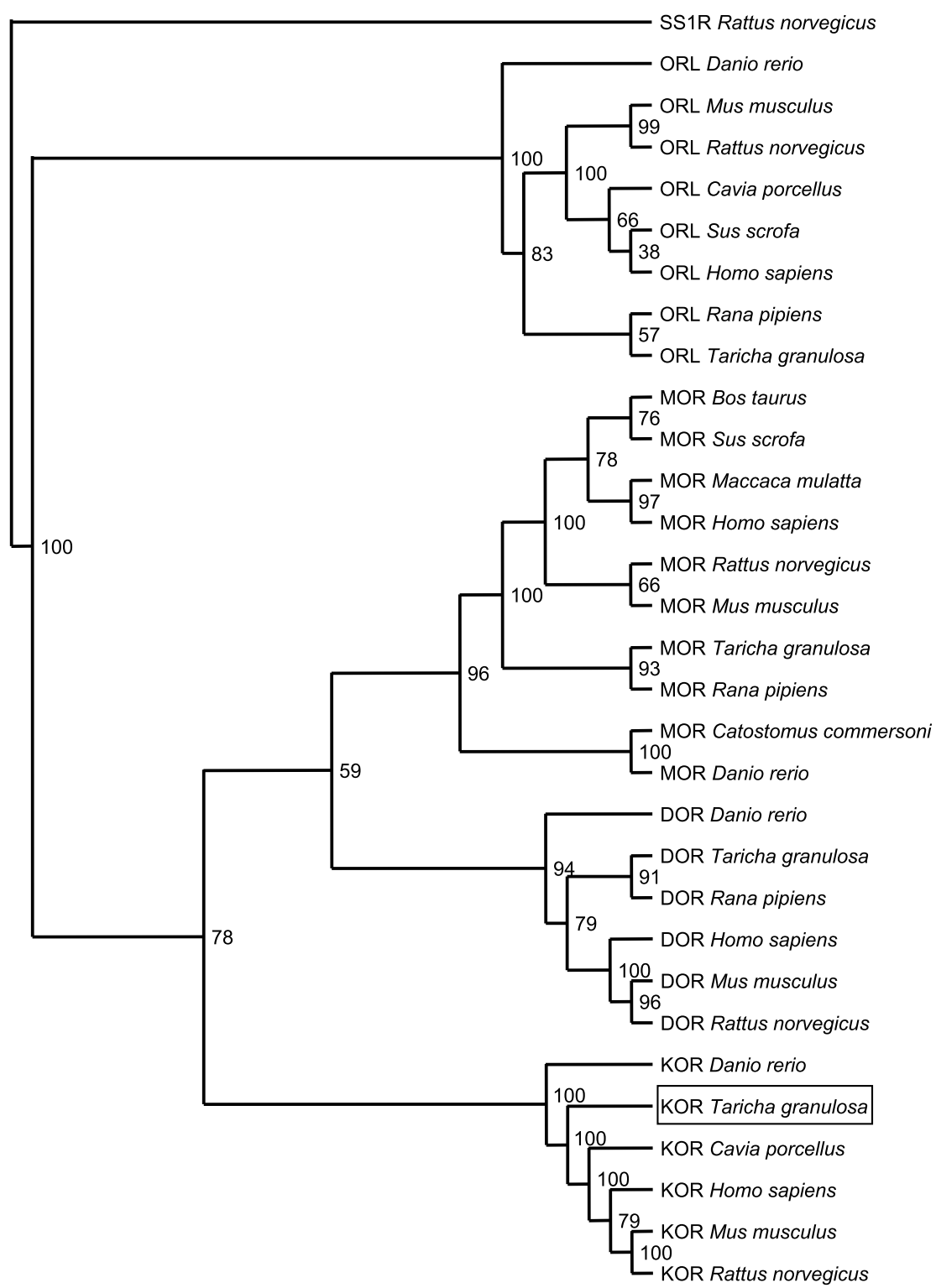

Figure 3 A phylogenetic tree of known full-length opioid receptor amino acid sequences generated by maximum parsimony (PHYLIP 3.6). The tree is rooted in rat somatostatin receptor type 1 (SS1R). Bootstrap values are indicated at the nodes. The newt sequence (boxed) groups with the kappa opioid receptor sequences from other vertebrate classes. ORL, opioid receptor-like; MOR, mu opioid receptor; DOR, delta opioid receptor; KOR, kappa opioid receptor. Sequences for species other than T. granulosa were obtained from GenBank. Accession numbers: SS1R Rattus norvegicus, P28646; ORL Danio rerio, AAN46747.1; ORL Mus musculus, P35377; ORL Rattus norvegicus, NP_113757.1; ORL Cavia porcellus, P47748; ORL Sus scrofa, P79292; ORL Homo sapiens, NP_872588.1; ORL Rana pipiens, AAR08905.1; ORL Taricha granulosa, AAU26067.1; MOR Bos taurus, NP_776833.1; MOR Sus scrofa, Q95247; MOR Macacca mulatta, Q9 MYW9; MOR Homo sapiens, NP_000905.1; MOR Rattus norvegicus, NP_037203.1; MOR Mus musculus, P42866; MOR Taricha granulosa, AAV28689; NP_035143.1; MOR Rana pipiens, AAQ09991.1; MOR Catostomus commersoni, CAA71843.1; MOR Danio rerio, NP_571782.1; DOR Danio rerio, AAP86771.1; DOR Taricha granulosa, AAV28690.1; DOR Rana pipiens, AAQ09992.1; DOR Homo sapiens, NP_000902.2; DOR Mus musculus, NP_038650.2; DOR Rattus norvegicus, NP_036749.1; KOR Danio rerio, NP_878306.1; KOR Taricha granulosa, AAU15126; KOR Cavia porcellus, P41144 I; KOR Homo sapiens, NP_000903.2; KOR Mus musculus, NP_035141.1; KOR Rattus norvegicus, NP_058863.1. 


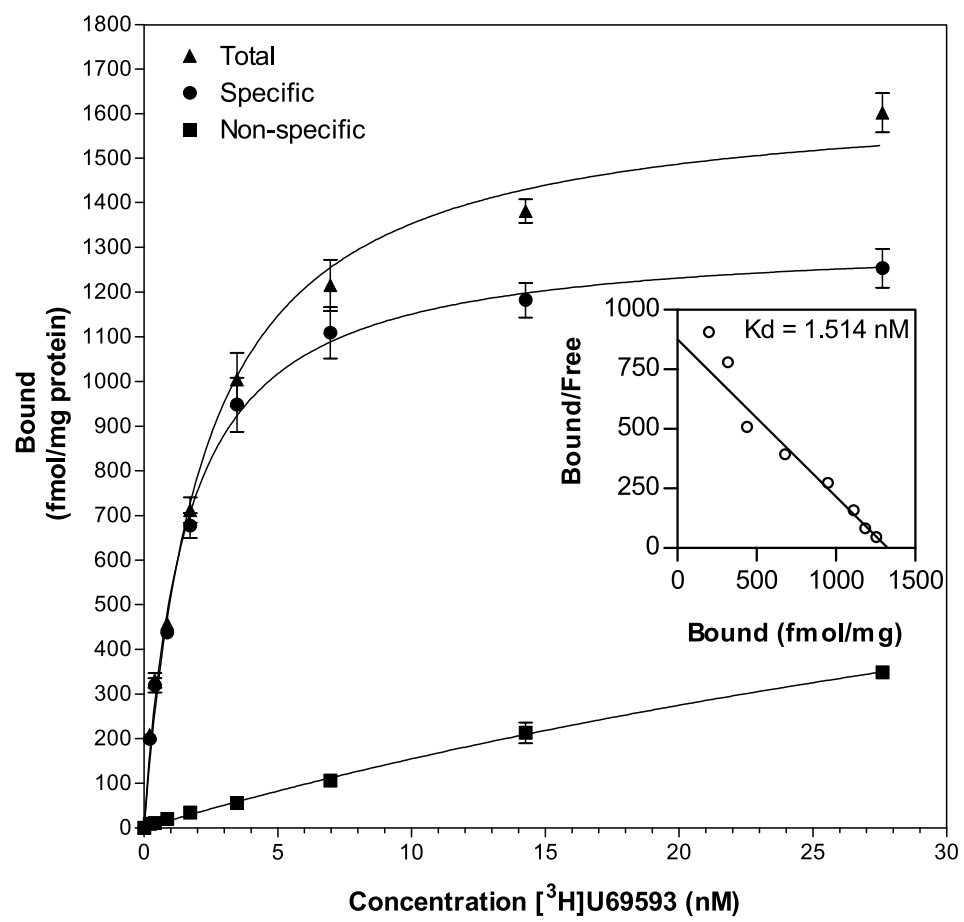

Figure 4 Saturation analysis of $\left[{ }^{3} \mathrm{H}\right] \mathrm{U} 69593$ binding to membranes isolated from COS-7 cells transiently expressing nKOR. Non-specific binding for each ligand dose was determined in the presence of $10 \mu \mathrm{M}$ nor-BNI. Each data point represents the mean \pm S.E.M. for triplicate measurements. Inset shows Scatchard analysis.

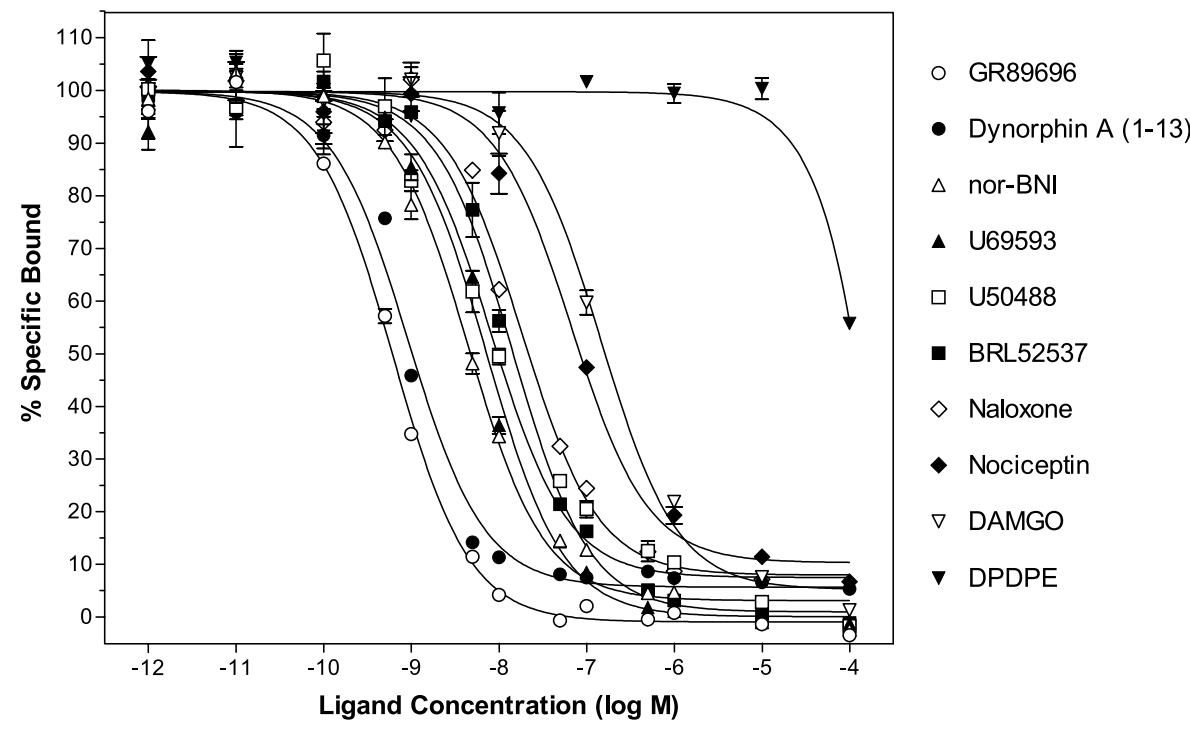

Figure 5 Inhibition of specific $\left[{ }^{3} \mathrm{H}\right] \mathrm{U} 69593$ binding to membranes from COS-7 cells transiently expressing nKOR. Approximately $2 \mathrm{nM}\left[{ }^{3} \mathrm{H}\right] \mathrm{U} 69593$ was used in all experiments (range= $1.9-2.9 \mathrm{nM}$ ); non specific binding was defined as radioactivity remaining bound in the presence of $10 \mu \mathrm{M}$ non-radioactive U69535. Each data point represents the mean \pm S.E.M. for triplicate measurements. 
Table 1 Summary of inhibition binding data obtained in experiments designed to assess the ability of various opioid ligands to displace $\left[{ }^{3} \mathrm{H}\right] \mathrm{U} 69593$ from membranes of COS-7 cells transiently expressing nKOR or neuronal P2 membranes prepared from Taricha brain

nKOR expressed in cOS-7 cells

Ligand

к-selective

GR89696

Dynorphin A(1-13)

nor-BNI

U69593

U50488

BRL52537

Non-selective

Naloxone

ORLI-selective Nociceptin

$\mu$-selective

DAMGO

$\delta$-selective

DPDPE

$\overline{\mathrm{IC}_{50}(\mathrm{nM}) \quad K_{\mathrm{i}}(\mathrm{nM})}$

Brain P2 neuronal pellets

$\overline{\mathrm{IC}_{50}(\mathrm{nM}) \quad K_{\mathrm{i}}(\mathrm{nM})}$

Starting with total RNA isolated from newt brains, degenerate PCR amplified a cDNA fragment that showed high sequence homology to the mammalian $\kappa$ receptors. Subsequently, RACE-PCR (using Tarichaspecific oligo primers) allowed us to extend the original
cDNA sequence in both directions, and culminated in amplification of a contiguous sequence representing a full-length cDNA encoding a protein of 385 amino acids. BLAST analysis of the deduced amino sequence again demonstrated highest sequence identity with known

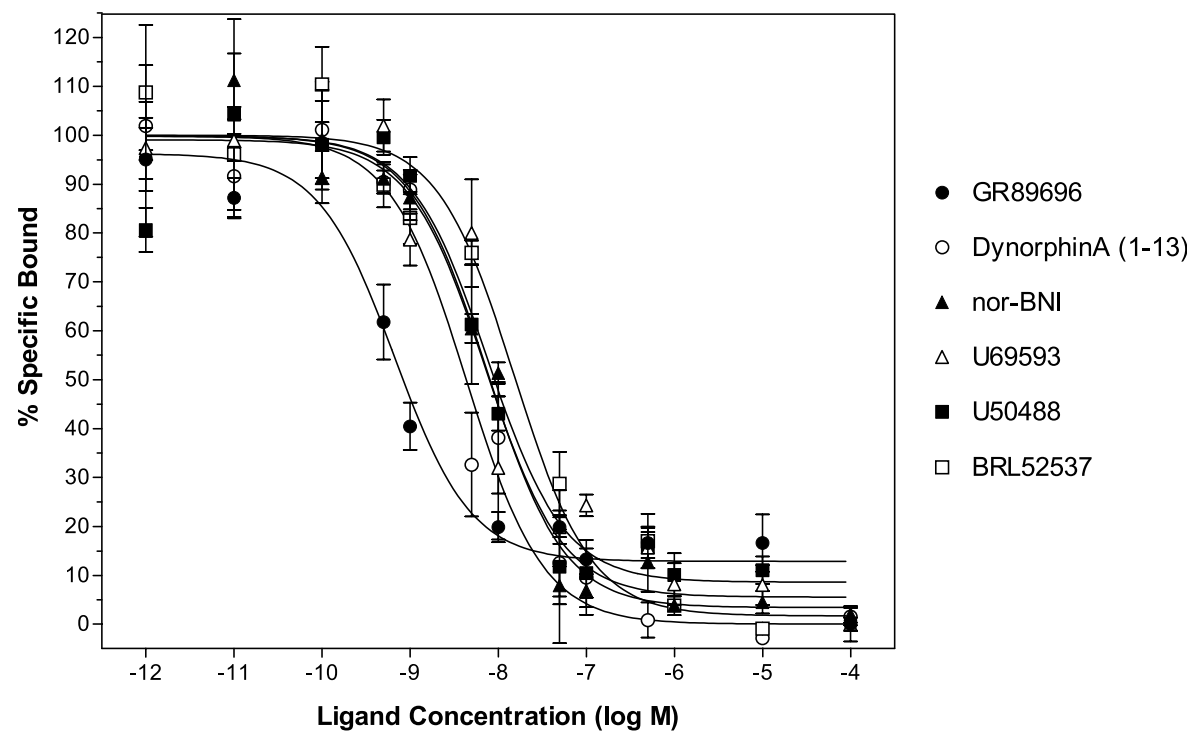

Figure 6 Inhibition of specific $\left[{ }^{3} \mathrm{H}\right] \mathrm{U} 69593$ binding to neuronal P2 membranes prepared from Taricha brains. Approximately $2 \mathrm{nM}\left[{ }^{3} \mathrm{H}\right] \mathrm{U} 69593$ was used in all experiments

(range $=1 \cdot 3-2 \cdot 1 \mathrm{nM}$ ); non-specific binding was defined as radioactivity remaining bound in the presence of $10 \mu \mathrm{M}$ non-radioactive U69593. Each data point represents the mean \pm S.E.M. for triplicate measurements. 
mammalian $\kappa$ opioid receptors, and maximum parsimony analysis showed that the amino acid sequence clustered with the other vertebrate $\kappa$ receptors that have been cloned. Analysis of the primary structure of the predicted protein revealed the presence of physical attributes shared by other $G$ protein-coupled receptors that have been identified as opioid receptors. Among these are the presence of seven hydrophobic transmembrane domains, potential sites for N-linked glycosylation in the extracellular N-terminal domain, a conserved DRY motif at the beginning of the second putative intracellular loop, conserved cysteine residues in the second and third extracellular loops, and potential sites for palmitoylation and phosphorylation in intracellular loops as well as the intracellular C-terminal domain (Minami \& Satoh 1995). Based on its sequence, we tentatively identified the cDNA we cloned from the brain of $\mathcal{T}$. granulosa as the nKOR.

Membranes isolated from COS-7 cells transiently expressing $\mathrm{nKOR}$ possessed a saturable, high-affinity $\left(K_{\mathrm{d}}=1.51 \mathrm{nM}\right)$ binding site for the $\kappa$-selective agonist $\left[{ }^{3} \mathrm{H}\right] \mathrm{U69593}$; no such binding was detected in COS-7 cells that were not transfected. This measurement agrees closely with values reported previously for $\left[{ }^{3} \mathrm{H}\right] \mathrm{U} 69593$ in studies describing pharmacological profiles of mammalian $\kappa$ receptors expressed in COS cells, including rat $\left(K_{\mathrm{d}}=1.46 \mathrm{nM}\right)$ (Meng et al. 1993), guinea pig $\left(K_{\mathrm{d}}=1.17 \mathrm{nM}\right)$ (Xie et al. 1994) and human $\left(K_{\mathrm{d}}=1.49 \mathrm{nM}\right)($ Simonin et al. 1995$) \kappa$ receptors. The $K_{\mathrm{d}}$ values reported so far for $\left[{ }^{3} \mathrm{H}\right] \mathrm{U} 69593$ in saturation binding assays employing amphibian brain tissues are slightly higher than our estimate for nKOR: $6 \cdot 81 \mathrm{nM}$ for the northern grass frog (R. pipiens) (Newman et al. 2002) and $15.3 \mathrm{nM}$ in the European water frog (R. esculenta) (Benyhe et al. 1992).

In competition binding experiments designed to assess the affinity of various opioid ligands for the cloned newt receptor, membranes isolated from COS-7 cells transiently expressing nKOR showed high affinity for the $\kappa$-selective agonists GR89696, dynorphin A(1-13), U69593, U50488 and BRL52537, as well as the $\kappa$-selective antagonist nor-BNI and the non-selective antagonist naloxone. In mammals, high affinity for both U69593 and U50488 is considered one means of pharmacologically distinguishing $\kappa$ receptors from the other opioid receptor classes, since these agonists bind potently and specifically to $\mathrm{K}$ receptors (Zukin et al. 1988, Clark et al. 1989) but do not bind to either $\delta$ or $\mu$ receptors (Raynor et al. 1996).

Competition binding assays conducted with neuronal P2 membranes prepared from Taricha brains revealed rank order potencies and affinity constants for $\kappa$ ligands that matched closely the results of experiments employing membranes isolated from COS-7 cells transiently expressing nKOR. All together, our results are consistent with the idea that nKOR is, in fact, a newt $\kappa$ opioid receptor, and that nKOR and the $\kappa$ binding site present in whole newt brains are one and the same.

Like its mammalian counterparts, the expressed nKOR demonstrated little, if any, affinity for the $\delta$-selective agonist DPDPE $\left(K_{\mathrm{i}}=979 \mathrm{nM}\right)$. In contrast, the expressed nKOR showed moderate affinity for DAMGO $\left(K_{\mathrm{i}}=55.4 \mathrm{nM}\right)$, unlike the cloned/expressed mammalian $\kappa$ receptors, none of which demonstrate measurable affinity for this $\mu$-selective agonist (Meng et al. 1993, Yasuda et al. 1993, Mansson et al. 1994, Xie et al. 1994, Simonin et al. 1995). Interestingly, the expressed nKOR showed moderately high affinity $\left(K_{\mathrm{i}}=23 \cdot 2 \mathrm{nM}\right)$ for nociceptin (orphanin FQ), an ORL1selective agonist and the endogenous ligand for the ORL1 receptor (Meunier et al. 1995, Reinscheid et al. 1995). In mammals, nociceptin displays essentially no affinity for the canonical $\kappa, \delta$ and/or $\mu$ opioid receptors (Meunier et al. 1995, Reinscheid et al. 1995, Meng et al. 1996, Pan et al. 2002) and, despite a high degree of sequence homology shared among all of the opioid receptor classes, the ORL1 receptor in mammals does not recognize the classic opioid drugs that bind with high affinity to $\kappa, \delta$ and $\mu$ opioid receptors (Owens \& Akil 2002). Such discrimination is especially interesting when it is appreciated that nociceptin (FGGFTGARK SARKLANQ bears a significant degree of sequence identity to dynorphin A (YGGFLRRIRPKLKWDNQ) and belongs to the family of opioid peptides (Danielson et al. 2001).

We recently cloned, expressed and characterized an ORL1 receptor from the brain of Taricha (nORL1), and found that the expressed nORL1 binds nociceptin and dynorphin $\mathrm{A}(1-13)$ with high affinity (Walthers et al. 2005). Research into the physiology of mammalian opioid ligand-receptor interactions has supported the idea of a strict functional dichotomy, in which the classic opioids interact with $\mu, \kappa$ and/or $\delta$ receptors to produce analgesia and nociceptin-ORL1 interactions act in an opposing fashion (Reinscheid et al. 1998, Danielson et al. 2001). Our results suggest that, in contrast to mammals, newts have ORLl and $\kappa$ opioid receptors that recognize both nociceptin and dynorphin. This apparent lower specificity might reflect a more basal characteristic of opioid receptors.

Prior research shows that, among $G$ protein-coupled receptors, the $\mathrm{N}$-terminal domain and extracellular loops specify receptor-ligand selectivity (Akil et al. 1996). Studies involving expression of chimeric opioid receptors, as well as modeling experiments simulating receptor-ligand interactions suggest that the second extracellular loop of the $\kappa$ receptor may play a crucial role in recognition of endogenous ligands (Wang et al. 1994, Raynor et al. 1996, Paterlini et al. 1997). We found that the N-terminal domain and the second and third extracellular loops (and to a lesser degree the 
first extracellular loop) of nKOR diverge from the amino acid sequences reported for the mammalian $\kappa$ receptors that have been cloned to date. These differences might confer different standards for ligand selectivity and account for the fact that nKOR recognizes DAMGO and nociceptin, whereas mammalian $\kappa$ opioid receptors do not. Li et al. (1996) noted that a valine residue that is highly conserved in the first extracellular loop of all mammalian $\kappa$ receptors is replaced by a negatively charged glutamate residue in a partial cDNA sequence isolated for a frog $\kappa$ receptor, and speculated that the amphibian $\kappa$ receptor might have the capacity to bind nociceptin. It turns out that nKOR also possesses glutamate instead of valine at the position in question, and does bind nociceptin, as predicted.

Multiple, distinct $\kappa$ receptor subtypes $\left(\kappa_{1}, \kappa_{1 \mathrm{a} / \mathrm{b}}, \kappa_{2}\right.$, $\kappa_{2 \mathrm{a} / \mathrm{b}}, \kappa_{3}$ ) have been proposed based partly on binding studies revealing multiple sites possessing different ligand affinities, partly on the basis of pharmacological experiments demonstrating selective interactions with various ligands, and partly on the basis of varying anatomical distributions (Zukin et al. 1988, Clark et al. 1989, Benyhe et al. 1990, Rothman et al. 1990, Wollemann et al. 1993). One group has reported that two transcripts are derived from a single gene encoding the rat $\kappa$ receptor, demonstrating the potential for multiple $\kappa$ receptor splice variants (Yakovlev et al. 1995). In general, however, molecular cloning studies have failed to identify cDNA sequences that would account for the multiplicity of $\kappa$ receptor subtypes. Our results do not rule out the possibility that multiple nKOR subtypes and/or splice variants exist in the newt brain; however, we found no evidence for the expression of more than one type of $\kappa$ receptor. In multiple, redundant, PGR procedures, we amplified a product that appeared as a single band on ethidium bromide-stained gels, and the sequence of the amplified cDNA was always the same. Additionally, we found that the binding affinities and rank order potencies for $\kappa$-selective ligands were essentially the same, regardless of whether binding assays were conducted using membranes isolated from COS-7 cells transiently expressing the cloned nKOR or neuronal P2 membranes prepared from whole Taricha brains. Our observations are consistent with the notion that only one type of $\kappa$ opioid receptor mRNA is expressed in newt brains.

Recent studies show that $\mathrm{G}$ protein-coupled receptors can function in homo- and hetero-oligomeric complexes (Dean et al. 2001, Angers et al. 2002, Lee et al. 2003); co-expression experiments demonstrate the formation of opioid receptor heterodimers that exhibit novel ligandbinding properties compared with either receptor expressed alone (Jordan \& Devi 1999, George et al. 2000, Pan et al. 2002). For example, stable co-expression of $\kappa$ and $\delta$ opioid receptors results in the formation of a functional $\kappa-\delta$ heterodimer exhibiting binding properties that match the $\kappa_{2}$ receptor subtype (Jordan \& Devi 1999). Whether or not other functional combinations of opioid receptors might explain the apparent diversity of $\kappa$ receptor subtypes remains unresolved. We have recently cloned full-length cDNA sequences for Taricha $\delta$ and $\mu$ opioid receptors, and it will be interesting to test the hypothesis that co-expression of two or more types of Taricha opioid receptors may generate novel binding profiles matching the pharmacology described for one or more of the proposed $\kappa$ receptor subtypes.

Early studies with rough-skinned newts demonstrated rapid and potent suppression of courtship behavior (amplectic clasping of females) in males subjected to acute stress or treated with the steroid corticosterone (Moore \& Miller 1984). Similarly, male newts treated with bremazocine and ethylketocyclazocine, both $\kappa$-selective agonists, showed rapid inhibition of amplectic clasping (Deviche \& Moore 1987). Subsequently, it was discovered that there is a highly specific, saturable corticosterone-binding site in neuronal membranes isolated from Taricha brains (Orchinik et al. 1991) that appears to be a $G$ protein-coupled receptor (Orchinik et al. 1992). In a series of ligand-binding competition experiments designed to screen various classes of ligands for ability to displace $\left[{ }^{3} \mathrm{H}\right]$ corticosterone from neuronal membranes, it was found that some, but not all, $\kappa$ ligands were effective (Evans et al. 2000). Dynorphin A(1-13), U50488, bremazocine and ethylketocyclazocine were able to displace some (up to $70 \%$ ) of $\left[{ }^{3} \mathrm{H}\right]$ corticosterone specific binding. U69593 (a $\kappa$-selective agonist) and nor-BNI (a $\kappa$-selective antagonist) were found to be ineffective. These results, together with the behavioral data collected previously, were consistent with the hypothesis that the membrane corticosterone receptor in the Taricha brain is located on a $\kappa$ opioid-like receptor (Evans et al. 2000). The Taricha brain $\kappa$ receptor reported here binds all of the $\kappa$-selective ligands with high affinity, including dynorphin $\mathrm{A}(1-13)$, U50488, nor-BNI and U69593. In addition, membranes isolated from COS-7 cells transiently expressing nKOR showed low, or no, specific binding of $\left[{ }^{3} \mathrm{H}\right]$ corticosterone (data not shown). We conclude, therefore, that nKOR is not the membrane receptor responsible for binding corticosterone in the Taricha brain.

In summary, we have cloned a full-length cDNA encoding a $\kappa$ opioid receptor from the brain of an amphibian, the rough-skinned newt $T$. granulosa. This receptor is similar to $\kappa$ receptors cloned previously from other vertebrates, but shows interesting pharmacological differences with respect to ligand-binding profiles. The newt brain $\kappa$ receptor does not appear to be the corticosterone-binding site described by our laboratory previously, but it remains possible that co-expression of 
two or more opioid receptor types (including the $\kappa$ receptor) may result in the formation of an oligomeric complex possessing novel binding properties.

\section{Acknowledgements}

T Filtz, M Leid and M Schimerlik listened patiently and offered valuable advice. B Baird kindly provided cell culture facilities. C S B extends special thanks to O Asis. This work was supported by grant \#R01 MH62027 to F L M from the National Institute of Mental Health. Some compounds used in competition binding experiments were generously provided by the National Institute on Drug Abuse, as part of the NIDA Drug Supply Program.

\section{References}

Akil H, Meng F, Mansour A, Thompson R, Xie GX \& Watson S 1996 Cloning and characterization of multiple opioid receptors. NIDA Research Monograph 161 127-140.

Angers S, Salahpour A \& Bouvier M 2002 Dimerization: an emerging concept for $\mathrm{G}$ protein-coupled receptor ontogeny and function. Annual Review of Pharmacology and Toxicology $\mathbf{4 2}$ 409-435.

Benyhe S, Varga E, Hepp J, Magyar A, Borsodi A \& Wollemann M 1990 Characterization of kappa 1 and kappa 2 opioid binding sites in frog (Rana esculenta) brain membrane preparation. Neurochemistry Research 15 899-904.

Benyhe S, Szucs M, Borsodi A \& Wollemann M 1992 Species differences in the stereoselectivity of kappa opioid binding sites for $\left[{ }^{3} \mathrm{H}\right] \mathrm{U}-69593$ and $\left[{ }^{3} \mathrm{H}\right]$ ethylketocyclazocine. Life Sciences $\mathbf{5 1}$ $1647-1655$.

Benyhe S, Simon J, Borsodi A, Wollemann M \& Barnard EA 1994 $\left[{ }^{3} \mathrm{H}\right]$ dynorphin-8 binding sites in frog (Rana esculenta) brain membranes. Neuropeptides 26 359-364.

Bloom FE 1983 The endorphins: a growing family of pharmacologically pertinent peptides. Annual Review of Pharmacology and Toxicology 23 151-170.

Borsodi A, Khan A, Simon J, Benyhe S, Hepp J, Wollemann M \& Medzihradszky K 1986 Purification of kappa-opioid receptor subtype to apparent homogeneity from frog brain. NIDA Research Monograph 75 1-4.

Chavkin C, James IF \& Goldstein A 1982 Dynorphin is a specific endogenous ligand of the kappa opioid receptor. Science $\mathbf{2 1 5}$ $413-415$

Chen Y, Mestek A, Liu J \& Yu L 1993 Molecular cloning of a rat kappa opioid receptor reveals sequence similarities to the $\mathrm{mu}$ and delta opioid receptors. Biochemical fournal 295 625-628.

Clark JA, Liu L, Price M, Hersh B, Edelson M \& Pasternak GW 1989 Kappa opiate receptor multiplicity: evidence for two U50,488-sensitive kappa 1 subtypes and a novel kappa 3 subtype. Journal of Pharmacology and Experimental Therapeutics 251 461-468.

Cone RI \& Goldstein A 1982 A dynorphin-like opioid in the central nervous system of an amphibian. PNAS 79 3345-3349.

Danielson PB, Hoversten MT, Fitzpatrick M, Schreck C, Akil H \& Dores RM 2001 Sturgeon orphanin, a molecular 'fossil' that bridges the gap between the opioids and orphanin FQ/nociceptin. Fournal of Biological Chemistry $27622114-22119$.

Darlison MG, Greten FR, Harvey RJ, Kreienkamp HJ, Stuhmer T, Zwiers H, Lederis K \& Richter D 1997 Opioid receptors from a lower vertebrate (Catostomus commersoni): sequence, pharmacology, coupling to a G-protein-gated inward-rectifying potassium channel (GIRKl), and evolution. PNAS $948214-8219$.

Dean MK, Higgs C, Smith RE, Bywater RP, Snell CR, Scott PD, Upton GJ, Howe TJ \& Reynolds CA 2001 Dimerization of G-protein-coupled receptors. Fournal of Medical Chemistry 44 4595-4614.

Deviche P \& Moore FL 1987 Opioid kappa-receptor agonists suppress sexual behaviors in male rough-skinned newts (Taricha granulosa). Hormones and Behavior 21 371-383.

Deviche P, Lowry CA \& Moore FL 1989 Opiate control of spontaneous locomotor activity in a urodele amphibian. Pharmacology, Biochemistry, and Behavior 34 753-757.

Deviche P, Cotter P \& Gulledge CG 1993 Identification, partial characterization, and hypothalamic distribution of kappa, mu, and delta opioid receptors in a passerine songbird (funco hyemalis). Brain Research 614 220-226.

Evans SJ, Searcy BT \& Moore FL 2000 A subset of kappa opioid ligands bind to the membrane glucocorticoid receptor in an amphibian brain. Endocrinology $1412294-2300$.

Felsenstein J 1989 PHYLIP - Phylogeny Inference Package (Version 3.2). Cladistics 5 164-166.

Felsenstein J 2004 PHYLIP (Phylogeny Inference Package) version 3.6. Distributed by the author. Department of Genome Sciences, University of Washington, Seattle, WA.

George SR, Fan T, Xie Z, Tse R, Tam V, Varghese G \& O'Dowd BF 2000 Oligomerization of mu- and delta-opioid receptors. Generation of novel functional properties. Fournal of Biological Chemistry 275 26128-26135.

Goldstein A \& Naidu A 1989 Multiple opioid receptors: ligand selectivity profiles and binding site signatures. Molecular Pharmacology 36 265-272.

Janecka A, Fichna J \& Janecki T 2004 Opioid receptors and their ligands. Current Topics in Medicinal Chemistry 4 1-17.

Jordan BA \& Devi LA 1999 G-protein-coupled receptor heterodimerization modulates receptor function. Nature $\mathbf{3 9 9}$ $697-700$

Kozak M 1989 The scanning model for translation: an update. Fournal of Cell Biology 108 229-241.

Krogh A, Larsson B, von Heijne G \& Sonnhammer EL 2001 Predicting transmembrane protein topology with a hidden Markov model: application to complete genomes. Fournal of Molecular Biology 305 567-580.

Lahti RA, VonVoigtlander PF \& Barsuhn C 1982 Properties of a selective kappa agonist, U-50,488H. Life Sciences 31 2257-2260.

Lahti RA, Mickelson MM, McCall JM \& Von Voigtlander PF 1985 $\left[{ }^{3} \mathrm{H}\right] \mathrm{U}-69593$ a highly selective ligand for the opioid kappa receptor. European Fournal of Pharmacology 109 281-284.

Lee SP, O'Dowd BF \& George SR 2003 Homo- and hetero-oligomerization of $\mathrm{G}$ protein-coupled receptors. Life Sciences 74 173-180

Li X, Keith DE Jr \& Evans CJ 1996 Multiple opioid receptor-like genes are identified in diverse vertebrate phyla. FEBS Letters 397 25-29.

Lowry CA, Deviche P \& Moore FL 1990 Effects of corticotropin-releasing factor (CRF) and opiates on amphibian locomotion. Brain Research 513 94-100.

Mansson E, Bare L \& Yang D 1994 Isolation of a human kappa opioid receptor cDNA from placenta. Biochemical and Biophysical Research Communications 202 1431-1437.

Meng F, Xie GX, Thompson RC, Mansour A, Goldstein A, Watson SJ \& Akil H 1993 Cloning and pharmacological characterization of a rat kappa opioid receptor. PNAS $909954-9958$.

Meng F, Taylor LP, Hoversten MT, Ueda Y, Ardati A, Reinscheid RK, Monsma FJ, Watson SJ, Civelli O \& Akil H 1996 Moving from the orphanin FQ receptor to an opioid receptor using four point mutations. Fournal of Biological Chemistry 271 32016-32020. 
Meunier JC, Mollereau C, Toll L, Suaudeau C, Moisand C, Alvinerie P, Butour JL, Guillemot JC, Ferrara P, Monsarrat B et al. 1995 Isolation and structure of the endogenous agonist of opioid receptor-like ORL1 receptor. Nature 377 532-535.

Minami M \& Satoh M 1995 Molecular biology of the opioid receptors: structures, functions and distributions. Neuroscience Research 23 121-145.

Minami M, Toya T, Katao Y, Maekawa K, Nakamura S, Onogi T, Kaneko S \& Satoh M 1993 Gloning and expression of a cDNA for the rat kappa-opioid receptor. FEBS Letters 329 291-295.

Moller S, Croning MD \& Apweiler R 2001 Evaluation of methods for the prediction of membrane spanning regions. Bioinformatics $\mathbf{1 7}$ 646-653.

Moore FL \& Miller LJ 1984 Stress-induced inhibition of sexual behavior: corticosterone inhibits courtship behaviors of a male amphibian (Taricha granulosa). Hormones and Behavior 18 400-410.

Moore FL \& Orchinik M 1994 Membrane receptors for corticosterone: a mechanism for rapid behavioral responses in an amphibian. Hormones and Behavior 28 512-519.

Newman LC, Sands SS, Wallace DR \& Stevens CW 2002 Characterization of mu, kappa, and delta opioid binding in amphibian whole brain tissue homogenates. Fournal of Pharmacology and Experimental Therapeutics $301364-370$.

Orchinik M, Murray TF \& Moore FL 1991 A corticosteroid receptor in neuronal membranes. Science 252 1848-1851.

Orchinik M, Murray TF, Franklin PH \& Moore FL 1992 Guanyl nucleotides modulate binding to steroid receptors in neuronal membranes. PNAS 89 3830-3834.

Owens CE \& Akil H 2002 Determinants of ligand selectivity at the kappa-receptor based on the structure of the orphanin FQ receptor. Fournal of Pharmacology and Experimental Therapeutics $\mathbf{3 0 0}$ 992-999.

Pan YX, Bolan E \& Pasternak GW 2002 Dimerization of morphine and orphanin FQ/nociceptin receptors: generation of a novel opioid receptor subtype. Biochemical and Biophysical Research Communications 297 659-663.

Paterlini G, Portoghese PS \& Ferguson DM 1997 Molecular simulation of dynorphin A-(1-10) binding to extracellular loop 2 of the kappa-opioid receptor. A model for receptor activation. Journal of Medicinal Chemistry 40 3254-3262.

Pfeiffer A, Brantl V, Herz A \& Emrich HM 1986 Psychotomimesis mediated by kappa opiate receptors. Science 233 774-776.

Pfeiffer M, Koch T, Schroder H, Laugsch M, Hollt V \& Schulz S 2002 Heterodimerization of somatostatin and opioid receptors cross-modulates phosphorylation, internalization, and desensitization. Fournal of Biological Chemistry 277 19762-19772

Piercey MF, Lahti RA, Schroeder LA, Einspahr FJ \& Barsuhn C 1982 U-50488H, a pure kappa receptor agonist with spinal analgesic loci in the mouse. Life Sciences 31 1197-1200.

Raynor K, Kong H, Law S, Heerding J, Tallent M, Livingston F, Hines J \& Reisine T 1996 Molecular biology of opioid receptors. NIDA Research Monograph 161 83-103.

Reinscheid RK, Nothacker HP, Bourson A, Ardati A, Henningsen RA, Bunzow JR, Grandy DK, Langen H, Monsma FJ Jr \& Civelli O 1995 Orphanin FQ: a neuropeptide that activates an opioid-like G protein-coupled receptor. Science 270 792-794.

Reinscheid RK, Higelin J, Henningsen RA, Monsma FJ Jr \& Civelli O 1998 Structures that delineate orphanin FQ and dynorphin A pharmacological selectivities. Fournal of Biological Chemistry 273 1490-1495.

Reisine T \& Bell GI 1993 Molecular biology of opioid receptors. Trends in Neuroscience 16 506-510.

Rothman RB, Bykov V, de Costa BR, Jacobson AE, Rice KC \& Brady LS 1990 Interaction of endogenous opioid peptides and other drugs with four kappa opioid binding sites in guinea pig brain. Peptides 11 311-331.
Rozen S \& Skaletsky H 2000 Primer3 on the WWW for general users and for biologist programmers. In Bioinformatics Methods and Protocols: Methods in Molecular Biology, pp 365-386. Eds S Krawetz \& S Misener. Totowa, NJ: Humana Press.

Ruegg UT, Hiller JM \& Simon EJ 1980 Solubilization of an active opiate receptor from Bufo marinus. European Fournal of Pharmacology $64367-368$.

Ruegg UT, Cuenod S, Hiller JM, Gioannini T, Howells RD \& Simon EJ 1981 Characterization and partial purification of solubilized active opiate receptors from toad brain. PNAS 78 4635-4638.

Simon EJ, Hiller JM, Groth J, Itzhak Y, Holland MJ \& Beck SG 1982 The nature of opiate receptors in toad brain. Life Sciences $\mathbf{3 1}$ 1367-1370.

Simon J, Szucs M, Benyhe S, Borsodi A, Zeman P \& Wollemann M 1984 Solubilization and characterization of opioid binding sites from frog (Rana esculenta) brain. Fournal of Neurochemistry $\mathbf{4 3}$ 957-963.

Simon J, Benyhe S, Hepp J, Khan A, Borsodi A, Szucs M, Medzihradszky K \& Wollemann M 1987 Purification of a kappa-opioid receptor subtype from frog brain. Neuropeptides $\mathbf{1 0}$ 19-28.

Simon J, Benyhe S, Hepp J, Varga E, Medzihradszky K, Borsodi A \& Wollemann M 1990 Method for isolation of kappa-opioid binding sites by dynorphin affinity chromatography. Fournal of Neuroscience Research 25 549-555.

Simonin F, Gaveriaux-Ruff C, Befort K, Matthes H, Lannes B, Micheletti G, Mattei MG, Charron G, Bloch B \& Kieffer B 1995 kappa-Opioid receptor in humans: cDNA and genomic cloning, chromosomal assignment, functional expression, pharmacology, and expression pattern in the central nervous system. PNAS 92 7006-7010.

Stevens CW, Pezalla PD \& Yaksh TL 1987 Spinal antinociceptive action of three representative opioid peptides in frogs. Brain Research 402 201-203.

Thompson JD, Gibson TJ, Plewniak F, Jeanmougin F \& Higgins DG 1997 The CLUSTAL_X windows interface: flexible strategies for multiple sequence alignment aided by quality analysis tools. Nucleic Acids Research 25 4876-4882.

Tortella FC, Rose J, Robles L, Moreton JE, Hughes J \& Hunter JC 1997 EEG spectral analysis of the neuroprotective kappa opioids enadoline and PD117302. Fournal of Pharmacology and Experimental Therapeutics 282 286-293.

Tusnady GE \& Simon I 2001 The HMMTOP transmembrane topology prediction server. Bioinformatics 17 849-850.

Waldhoer M, Bartlett SE \& Whistler JL 2004 Opioid receptors. Annual Review of Biochemistry 73 953-990.

Walthers EA, Bradford CS \& Moore FL 2005 Cloning, pharmacological characterization, and tissue distribution of an ORL1-like opioid receptor from an amphibian, the rough-skinned newt Taricha granulosa. Fournal of Molecular Endocrinology 34 247-256.

Wang JB, Johnson PS, Wu JM, Wang WF \& Uhl GR 1994 Human kappa opiate receptor second extracellular loop elevates dynorphin's affinity for human mu/kappa chimeras. Fournal of Biological Chemistry $26925966-25969$.

Whittaker VP 1969 The synaptosome. In Handbook of Neurochemistry, vol 2, pp 327-364. Ed. A Lathja. New York: Plenum.

Wollemann M, Benyhe S \& Simon J 1993 The kappa-opioid receptor: evidence for the different subtypes. Life Sciences $\mathbf{5 2}$ 599-611.

Xie GX, Meng F, Mansour A, Thompson RC, Hoversten MT, Goldstein A, Watson SJ \& Akil H 1994 Primary structure and functional expression of a guinea pig kappa opioid (dynorphin) receptor. PNAS 91 3779-3783.

Yakovlev AG, Krueger KE \& Faden AI 1995 Structure and expression of a rat kappa opioid receptor gene. Fournal of Biological Chemistry 270 6421-6424. 
Yasuda K, Raynor K, Kong H, Breder CD, Takeda J, Reisine T \& Bell GI 1993 Cloning and functional comparison of kappa and delta opioid receptors from mouse brain. PNAS 90 6736-6740.

Zukin RS, Eghbali M, Olive D, Unterwald EM \& Tempel A 1988 Characterization and visualization of rat and guinea pig brain kappa opioid receptors: evidence for kappa 1 and kappa 2 opioid receptors. PNAS $\mathbf{8 5} 4061-4065$.

Received 21 December 2004

Accepted 25 January 2005

Made available online as an Accepted Preprint 31 January 2005 